\title{
Religiosity in 5-D: A Critical Note
}

Darwin L. Thomas

Brigham Young University

Andrew J. Weigert

University of Notre Dame

Follow this and additional works at: https://scholarsarchive.byu.edu/facpub

Part of the Religion Commons

Original Publication Citation

"'"'Religiosity in 5-D: A Critical Note,"' Social Forces 48 (December):26-263 (with A.J. Weigert)."

\section{BYU ScholarsArchive Citation}

Thomas, Darwin L. and Weigert, Andrew J., "Religiosity in 5-D: A Critical Note" (1969). Faculty Publications. 5687.

https://scholarsarchive.byu.edu/facpub/5687

This Peer-Reviewed Article is brought to you for free and open access by BYU ScholarsArchive. It has been accepted for inclusion in Faculty Publications by an authorized administrator of BYU ScholarsArchive. For more information, please contact ellen_amatangelo@byu.edu. 


\section{HEINONLINE}

DATE DOWNLOADED: Thu Feb 17 13:47:29 2022

SOURCE: Content Downloaded from HeinOnline

Citations:

Bluebook 21st ed.

Andrew J. Weigert \& Darwin L. Thomas, Religiosity in 5-D: A Critical Note, 48 Soc. F. 260 (1969).

ALWD 7th ed.

Andrew J. Weigert \& Darwin L. Thomas, Religiosity in 5-D: A Critical Note, 48 Soc. F. 260 (1969).

APA 7th ed.

Weigert, A. J., \& Thomas, D. L. (1969). Religiosity in 5-D: Critical Note. Social

Forces, 48(2), 260-263.

Chicago 17th ed.

Andrew J. Weigert; Darwin L. Thomas, "Religiosity in 5-D: A Critical Note," Social

Forces 48, no. 2 (December 1969): 260-263

McGill Guide 9th ed.

Andrew J. Weigert \& Darwin L. Thomas, "Religiosity in 5-D: A Critical Note" (1969) $48: 2$ Soc F 260.

AGLC 4th ed.

Andrew J. Weigert and Darwin L. Thomas, 'Religiosity in 5-D: A Critical Note' (1969) 48 Social Forces 260.

MLA 8th ed.

Weigert, Andrew J., and Darwin L. Thomas. "Religiosity in 5-D: A Critical Note."

Social Forces, vol. 48, no. 2, December 1969, p. 260-263. HeinOnline.

OSCOLA 4th ed.

Andrew J. Weigert \& Darwin L. Thomas, 'Religiosity in 5-D: A Critical Note' (1969) 48

Soc F 260

Provided by:

Howard W. Hunter Law Library, BYU

-- Your use of this HeinOnline PDF indicates your acceptance of HeinOnline's Terms and Conditions of the license agreement available at https://heinonline.org/HOL/License

-- The search text of this PDF is generated from uncorrected OCR text.

-- To obtain permission to use this article beyond the scope of your license, please use: Copyright Information 
Dimension of Social Status." American Sociological Review 19(August) :405-413.

1964 "Comment." Public Opinion Quarterly 28 (Summer) :322-330.

Mitchell, Robert Edward

1964 "Methodological Notes on a Theory of Status Crystallization." Public Opinion Quarterly 28(Summer) :315-325.

\section{Segal, David R.}

1967 "Classes, Strata and Parties in West Germany and the United States." Comparative Studies in Society and History 10 (October) :66-84.

Vermilye, Herbert Alan

1963 "On Measuring Status Inconsistency." American Sociological Review 28(June): 455-456.

\section{RELIGIOSITY IN 5-D: A CRITICAL NOTE}

\author{
ANDREW J. WEIGERT \\ University of Notre Dame
}

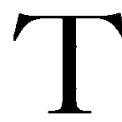

he equivocation which may result from violation of natural language or face validity is manifested in an article by Faulkner and DeJong (1966), "Religiosity in 5-D: An Empirical Analysis." The authors (1966:246-247) claim to be measuring and testing the associations among Glock's (1962) five dimensions of religiosity. They adequately refer to his dimensions as "experiential (feeling, emotion), ritualistic (religious behavior, i.e., church attendance), ideological (beliefs), intellectual (knowledge), and consequential (the effects in the secular world of the prior four dimensions)." The empirical "definition" of the dimensions, however, is given by the items used to measure them. It cannot be overemphasized that precisely at the juncture of the epistemic correlation, or the operationalization, the question of validity is not to be denied. The gap between stimulus and concept is one major arena for the sociology of social science.

$Q u a$ sociologist, the relevant explanation for the acceptance or rejection of a posited link between the concept and a measured event, i.e., the event as known, is the prevailing norms and expectations of the scientific community concerning the nature of evidence and the form of inference. In the Faulkner and DeJong article, these expectations are violated.

The items which they used to operationalize the ideological (belief) dimension correctly include such stimulus words as "believe, idea, opinion, and view" (all the items are listed on

\section{DARWIN L. THOMAS \\ Washington State University}

pages $252-254$ of their article). The face validity of these stimuli is acceptable. What conclusions about validity can be drawn, however, when the same semantic category of stimuli, viz., "view, opinion, believe," is found in three out of four items on the intellectual (knowledge) dimension? Campbell and Magill (1968: 83) also note that the knowledge dimension which Faulkner and DeJong present contains three "belief" items. The only knowledge (in the usual sense of the term) item is a question asking for the names of the four Gospels or the first five books of the Old Testament. The ritualistic (religious practice, e.g., church attendance) five-item scale includes the following two items (italics added): "Do you feel it is possible for an individual to develop a well-rounded religious life apart from the institutional church?" and "Do you believe that for your marriage the ceremony should be performed by:...?" The experiential (feeling, religious emotion) five-item scale includes only one item which asks about "feeling 'close" to the Divine. The other items ask whether you would "say" that religious commitment gives a certain purpose to life; or a sense of security in the face of death; how you would "respond" to a statement that religion provides a nonrational interpretation of existence; and whether you agree that faith is essential to a religious life. These items are proffered as operationalizations of real emotional or felt experiences of a Divine presence (Glock, 1962).

Most of the stimuli reported above are akin 
TABLE 1. CORRELATION MATRICES FOR DIMENSIONS OF RELIGIOSITY

\begin{tabular}{|c|c|c|c|c|c|c|}
\hline & \multicolumn{6}{|c|}{ Catholic Boys' Schools } \\
\hline & Belief & Experience & Knowledge & Belief & Experience & Knowledge \\
\hline \multirow[t]{2}{*}{$\begin{array}{l}\text { Experience } \ldots \ldots \ldots \ldots \ldots \ldots \ldots \ldots \\
\text { Knowledge. } \ldots \ldots \ldots \ldots \ldots \ldots \ldots \\
\text { Practice. } \ldots \ldots \ldots \ldots \ldots \ldots \ldots \ldots\end{array}$} & $\begin{array}{l}.52 \\
.02 \\
.46 \\
\\
.27 \\
.06 \\
.28\end{array}$ & $\begin{array}{c}\text { New York } \\
.07 \\
.44 \\
\text { San Juan } \\
.03 \\
.28\end{array}$ & .25 & $\begin{array}{l}.34 \\
.05 \\
.38 \\
\\
.38 \\
.22 \\
.25\end{array}$ & $\begin{array}{c}\text { St. Paul } \\
.01 \\
.28 \\
\text { Merida } \\
.07 \\
.28\end{array}$ & .18 \\
\hline & Stark and & Glock's Cathol & olic Sampleb & Stark and & Alock's Protest & tant Sampleb \\
\hline \multirow[t]{2}{*}{$\begin{array}{l}\text { Experience } \ldots \ldots \ldots \ldots \ldots \ldots \ldots \ldots \\
\text { Knowledge } \ldots \ldots \ldots \ldots \ldots \ldots \ldots \\
\text { Practice...... }\end{array}$} & $\begin{array}{l}.39 \\
.13 \\
.36\end{array}$ & $\begin{array}{l}.05 \\
.22\end{array}$ & .16 & $\begin{array}{l}.57 \\
.31 \\
.46\end{array}$ & $\begin{array}{l}.28 \\
.37\end{array}$ & .36 \\
\hline & Faulkner & $\begin{array}{l}\text { and DeJong's } \\
\text { Sample }\end{array}$ & 's Catholic & Faulkner & $\begin{array}{c}\text { and DeJong's } \\
\text { Sample }^{\text {C }}\end{array}$ & Protestant \\
\hline $\begin{array}{l}\text { Experience. } \ldots \ldots \ldots \ldots \ldots \ldots \ldots \\
\text { Knowiedge } \ldots \ldots \ldots \ldots \ldots \ldots \\
\text { Practice. } \ldots \ldots \ldots \ldots \ldots \ldots \ldots \\
\end{array}$ & $\begin{array}{l}.42 \\
.48 \\
.45\end{array}$ & $\begin{array}{l}.46 \\
.32\end{array}$ & .41 & $\begin{array}{l}.40 \\
.53 \\
.43\end{array}$ & $\begin{array}{l}.32 \\
.31\end{array}$ & .45 \\
\hline
\end{tabular}

aFrom Weigert (1968: 29)

bFrom Stark and Glock (1968: 177-178).

-From Faulkner and DeJong (1966: 251)

to the semantic category of "believe, opine, view," i.e., to the ideological category, yet they are presented as measures of different dimensions of religiosity. If the same semantic category of stimuli is used for allegedly different subscales, then appeal to a unidimensional Guttman scaling technique and correlation matrices rings empty indeed. Neither correlations nor unidimensionality is a guarantee of validity, especially if face validity or the usage of natural language is violated. This is even more regrettable in view of the authors' (1966: 252) purpose and conclusion that their "research is a step toward alleviating a major problem in the scientific study of religionthe development of measures of religious involvement." 1 The mixing of semantically similar stimuli against the indications of both face validity and the definitions of the original formulator makes crescive use of the measures or "findings" impossible. The unidimensionality of the scales is an "empiricistic" find-

1 Note that Glock (1962) and Stark and Glock (1968) call them dimensions of religious commitment. Most sociologists would not, it seems to us, consider involvement and commitment interchangeable terms. ing. The labeling of the scales according to definitions which they fail to operationalize is theoretical error. ${ }^{2}$

The possibility of crescive error is exemplified by Stark and Glock's (1968:179) uncritical reference to Faulkner and DeJong's article as a corroborating study and as revealing religiosity patterns "extremely similar" to their own. The relevant correlations are given in Table 1. Their comment demonstrates only that they were too seduced by the labels to inspect the items. In similar fashion, a subsequent article by Faulkner and DeJong (1968:39) carries the same error when it claims to present a scale composed of items which represent "all five dimensions of religiosity identified by Glock as characteristic of the religious devotee." An inspection of the items which they (1968:43-44) used revealed none that operationalized religious knowledge, practice or experience as these terms were defined by Glock. In another recent article, Lehman and Shriver (1968) uncritically refer to Faulkner and DeJong's 1966 study as support for the multidimensionality of religion.

2 Cf. Clayton (1968) for a replication of the findings and a repetition of the error. 
TABLE 2. RANKINGS OF INTERDIMENSIONAL CORRELATIONS OF RELIGIOSITY*

\begin{tabular}{|c|c|c|c|c|c|c|c|c|c|}
\hline \multirow[b]{3}{*}{$\begin{array}{l}\text { Paired Dimensions } \\
\text { of Religiosity }\end{array}$} & \multicolumn{4}{|c|}{ Catholic Boys' Schools } & \multirow{3}{*}{$\begin{array}{l}\text { Average } \\
\text { Rank- } \\
\text { ing } \\
\text { For } \\
\text { All } \\
\text { Schools }\end{array}$} & \multirow{2}{*}{\multicolumn{2}{|c|}{$\begin{array}{l}\text { Stark and } \\
\text { Glock's } \\
\text { Samples }\end{array}$}} & \multirow{2}{*}{\multicolumn{2}{|c|}{$\begin{array}{l}\text { Faulkner and } \\
\text { DeJong's } \\
\text { Samples }\end{array}$}} \\
\hline & \multirow[b]{2}{*}{$\begin{array}{l}\text { New } \\
\text { York }\end{array}$} & \multirow[b]{2}{*}{$\begin{array}{l}\text { St. } \\
\text { Paul }\end{array}$} & \multirow[b]{2}{*}{$\begin{array}{c}\text { San } \\
\text { Juan }\end{array}$} & \multirow[b]{2}{*}{ Merida } & & & & & \\
\hline & & & & & & $\begin{array}{l}\text { Cath- } \\
\text { olic }\end{array}$ & $\begin{array}{l}\text { Protes- } \\
\text { tant }\end{array}$ & $\begin{array}{l}\text { Cath- } \\
\text { olic }\end{array}$ & $\begin{array}{c}\text { Protes- } \\
\text { tant }\end{array}$ \\
\hline $\begin{array}{l}\text { Belief and experience } \\
\text { Belief and practice } \\
\text { Experience and practice } \\
\text { Knowledge and practice } \\
\text { Knowledge and belief } \\
\text { Knowledge and experience }\end{array}$ & $\begin{array}{l}1 \\
2 \\
3 \\
4 \\
6 \\
5\end{array}$ & $\begin{array}{l}2 \\
1 \\
3 \\
4 \\
5 \\
6\end{array}$ & $\begin{array}{l}3 \dagger \\
1.5 \\
1.5 \\
4 \\
5 \\
6\end{array}$ & $\begin{array}{l}1 \\
4 \\
3 \\
2 \\
5 \\
6\end{array}$ & $\begin{array}{l}1 \\
2 \\
3 \\
4 \\
5 \\
6\end{array}$ & $\begin{array}{l}1 \\
2 \\
3 \\
4 \\
5 \\
6\end{array}$ & $\begin{array}{l}1 \\
2 \\
3 \\
4 \dagger \\
5 \\
6\end{array}$ & $\begin{array}{l}4 \\
3 \dagger \\
6 \\
5 \dagger \\
1 \\
2\end{array}$ & $\begin{array}{l}4 \\
3 \\
6 \dagger \\
2 \\
1 \\
5\end{array}$ \\
\hline
\end{tabular}

*These rankings are derived from Table 1.

tOne hundredth of a poin $\mathrm{i}$ less than the preceding rank.

The semantic critique is corroborated empirically by a comparison of rankings of the interdimensional correlations of religiosity. The correlations are taken from Stark and Glock's (1968) and Faulkner and DeJong's (1966) Catholic and Protestant samples (cf. Table 1), and the authors' purposive samples from one middle-class, Catholic, boys' high school in each of the following cities: New York; St. Paul; San Juan, Puerto Rico; and Merida, Yucatan. ${ }^{3}$ The items which operationalized the dimensions of religiosity for the boys' samples were taken for the most part from Glock and Stark (1965), except for the knowledge items which were made more Catholic specific-e.g., when was the dogma of the Assumption proclaimed; who convened the Second Vatican Council, etc. The interdimensional correlation matrices for the four intrinsic (omitting the consequential) dimensions of religiosity and the ranking of the interdimensional correlations are given in Tables 1 and 2.

The result is an identical ranking for the average of the rankings of the four school samples with Stark and Glock's Catholic and Protestant samples. Although none of the school samples yielded this ranking, the Spearman $r$ 's between the New York, St. Paul, San Juan, and Merida rankings and the Stark and Glock "master" rankings are .94, .94, .81, .77, respectively. On the other hand, the Spearman $r$ 's between the rankings of Faulkner and DeJong's Catholic and Protestant samples and the

\footnotetext{
3 For a description of the samples, cf. Weigert (1968:35-36).
}

master rankings are -.49 and -.14 , respectively. These negative correlations lend empirical support to the semantic critique of Faulkner and DeJong's scales.

In spite of the empiricistic unidimensionality of their scales, the unusually high and similar correlations belie any claim to uncritical validity. The contrasts among the knowledge and belief correlations are especially illuminating. The average correlation between knowledge and belief for Faulkner and DeJong's samples is .51 as against .22 and .09 for the Stark and Glock, and Weigert and Thomas samples respectively.

The present critique indicates that Faulkner and DeJong's results may be more an artifact of the equivocation involved in the similarity of the semantic categories of the items than of defensible results from valid responses. Face validity may not be required for the application of computer technology, but the former cannot be ignored with impunity. Unless its demands are met, crescive findings are doomed to constant equivocation.

\section{REFERENCES}

Campbell, D. F., and D. Magill

1968 "Religious Involvement and Intellectuality Among College Students." Sociological Analysis 29(Summer) :79-93.

Clayton, Richard R.

1968 "Religiosity in 5-D: A Southern Test." Social Forces 47 (September) :80-83.

Faulkner, J. E., and G. DeJong

1966 "Religiosity in 5-D : An Empirical Analysis." Social Forces 45(December) :246254.

1968 "A Note on Religiosity and Moral Be- 
havior of a Sample of College Students."

Social Compass 15(1) :37-44.

Glock, Charles Y.

1962 "On the Study of Religious Commitment." Religious Education: Research Supplement 42(July-August): :98-110.

Glock, Charles Y., and Rodney Stark

1965 Religion and Society in Tension. Chicago: Rand McNally.

Lehman, E. C., Jr., and D. Shriver, Jr.

1968 "Academic Discipline as Predictive of
Faculty Religiosity." Social Forces 47 (December) :171-182.

Stark, Rodney, and Charles Y. Glock

1968 American Piety: The Nature of Religious Commitment. Berkeley: University of California Press.

Weigert, Andrew J.

1968 "Parent-Child Interaction Patterns and Adolescent Religiosity: A Cross-National Analysis." Unpublished Ph.D. dissertation, University of Minnesota.

\title{
ON MEASURING THE RELIGIOUS VARIABLE: REJOINDER TO WEIGERT AND THOMAS
}

\author{
JOSEPH E. FAULKNER
}

GORDON F. DeJONG

The Pennsylvania State University

$\mathrm{T}$ That there are varying perspectives of common concepts in the social sciences is one of the adversities to precise social measurement. Perhaps a brief passage from Alice in Wonderland (Carroll, $1951: 142$ ) illustrates the problem. Alice is in the garden of live flowers with the Red Queen:

I only wanted to see what the garden was like, your Majesty-

That's right, said the Queen patting her on the head, which Alice didn't like at all: though, when you say 'garden'-I've seen gardens, compared with which this would be a wilderness.

Alice didn't dare to argue the point, but went on: -and I thought I'd try and find my way to the top of that hill-

When you say 'hill,' the Queen interrupted, I could show you hills, in comparison with which you'd call that a valley.

No, I shouldn't, said Alice, surprised into contradicting her at last: a hill can't be a valley, you know. That would be nonsense-

The Red Queen shook her head. You may call it 'nonsense' if you like, she said, but I've heard nonsense, compared with which that would be as sensible as a dictionary!

In Weigert and Thomas' critical note the concern is not hills, valleys, and gardens but knowledge, experience, and practice of religion. Somewhat like the Queen, however, they view our conceptualization of the dimensions of religiosity with some contempt. Weigert and
Thomas are willing to admit, however, that the criteria for judging ". . . the relevant explanation for the acceptance or rejection of a posited link between the concept and a measured event, i.e., the event as known, is the prevailing norms and expectations of the scientific community concerning the nature of evidence and the form of inference." Since we, too, accept the norms and expectations of the scientific community as criteria for evaluation we offer additional evidence to judge whether or not such a violation of norms has indeed occurred. In particular, we wish to explore items used by members of the scientific community to measure the heavily criticized intellectual dimension, and to carefully scrutinize the authors' empirical data, again in light of prevailing scientific norms.

Have we failed to operationalize our dimensions with items which conform to the prevailing judgment in the scientific community concerning the event which is being measured? To answer the question, why not examine how the various dimensions of religiosity have been measured? Space in such a rejoinder as this precludes an extensive listing of all items which various investigators have used to measure the dimensions of religiosity. Let us, therefore, examine one dimension-the intellectual-since Weigert and Thomas seem to feel that the items in our intellectual scale depart markedly from 